\title{
RAZVOJ FIZIČNE GEOGRAFIJE NA LJUBLJANSKI UNIVERZI
}

dr. Franc Lovrenčak

Oddelek za geografijo, Filozofska fakulteta Univerze v Ljubljani

Aškerčeva 2, SI-I000 Ljubljana

e-mail: franc.lovrencak@guest.arnes.si

Pregledni znanstveni članek

COBISS 1.02

\section{Izvleček}

V prispevku je poskus prikaza razvoja fizične geografije na Oddelku za geografijo na Filozofski fakulteti Univerze v Ljubljani. Prikaz zajema zadnje dvajsetletno obdobje, od leta 1989 do 2009. Zajete so vse fizičnogeografske veje, ki so bile v tem obdobju zastopane v okviru katedre za fizično geografijo na tem oddelku. S predstavitvijo fizičnih geografov in njihovega dela, ki so se raziskovalno in pedagoško posvečali posameznim fizičnogeografskim vejam, naj bi se pokazalo, v kolikšni meri in na kakšen način so preučevali naravnogeografske značilnosti zlasti naše domače pokrajine.

Ključne besede: fizična geografija, veje fizične geografije, terenske vaje, laboratorij

\section{THE DEVELOPMENT OF PHYSICAL GEOGRAPHY AT THE UNIVERSITY OF LJUBLJANA}

\begin{abstract}
The paper is an attempt to present the development of physical geography at the Department of Geography at the Ljubljana's Faculty of Arts. The last two decades, from 1989 to 2009, are discussed, trying to include all its branches, forming the Chair of physical geography during this period. The presentation of physical geographers, who worked as researchers and teachers in particular branches of physical geography, should demonstrate the way and degree of studying physical-geographical characteristics of, mainly, Slovenian landscapes.
\end{abstract}

Key words: physical geography, branches of physical geography, field work, laboratory 


\section{UVOD}

Devetdesetletnica ustanove - pa naj bo iz različnih področij - je gotovo primerna, da se obudi spomin na dogajanja v tako dolgem obdobju. Tako je tudi ob 90-letnici Oddelka za geografijo na Filozofski fakulteti v Ljubljani. Ob taki obletnici se nudi priložnost, da pogledamo vsaj bežno, kaj se je dogajalo v letih pred njo in se ozremo tudi naprej. Ob okroglih obletnicah geografije na ljubljanski univerzi je bilo objavljenih več preglednih člankov: ob 30-letnici S. Ilešič (1950), ob 50-letnici S. Ilešič (1969), ob 70-letnici (Geografija in aktualna vprašanja prostorskega razvoja 1989) in ob 80-letnici (Razvojne možnosti Slovenije - Bodočnost mest 1999). V prispevkih o razvoju geografije je razvoj fizične geografije temeljito predstavil D. Radinja (1989), ko je obravnaval njen razvoj na ljubljanski univerzi od njene ustanovitve leta 1919 do 1989. Zato bo v tem prispevku zajeto le zadnje dvajsetletno obdobje, od 1989 do 2009.

\section{RAZVOJ FIZIČNE GEOGRAFIJE NA ODDELKU ZA GEOGRAFIJO PO LETU 1989}

Ko smo praznovali sedemdesetletnico geografije in s tem tudi fizične geografije (1989), je bila v okviru Katedre za fizično geografijo na Oddelku za geografijo Filozofske fakultete v Ljubljani zastopana večina vej fizične geografije (razen zoogeografije): geomorfologija, klimatogeografija, hidrogeografija ter pedogeografija in fitogeografija. Pedagoško in raziskovalno so te veje zastopali štirje univerzitetni učitelji in en asistent: profesorji Ivan Gams (geografija krasa), Darko Radinja (hidrogeografija), Jurij Kunaver (geomorfologija), Franc Lovrenčak (biogeografija s pedogeografijo), docent Dušan Plut (hidrogeografija) ter asistent Marjan Bat in stažist raziskovalec Darko Ogrin, skupno torej sedem fizičnih geografov. Vseh družbenih geografov pa je bilo takrat devet.

Po dvajsetih letih (2009) so se fizični geografiji posvečali profesorja Dušan Plut (hidrogeografija) in Karel Natek (geomorfologija) ter trije docenti: Darko Ogrin (klimatogeografija), Blaž Repe (pedogeografija z biogeografijo) in Uroš Stepišnik (geografija krasa). S fizičnogeografsko problematiko se ukvarjata še asistenta Tajan Trobec (hidrogeografija in pedogeografija z biogeografijo) in Matej Ogrin (klimatogeografija), skupaj sedem fizičnih geografov. Če primerjamo, kakšna je kadrovska zasedba v fizični in družbeni geografiji (v primerjavo niso všteti didaktika, varstvo okolja in pokrajinska ekologija), se fizični geografiji posveča pet učiteljev in dva asistenta. Med družbenimi geografi pa je šest učiteljev (Dejan Cigale, Andrej Černe, Marijan M. Klemenčič, Marko Krevs, Dejan Rebernik, Jernej Zupančič) in štirje asistenti (Simon Kušar, Irma Potočnik Slavič, Boštjan Rogelj, Katja Vintar Mally). Kadrovska zasedba je torej do neke mere uravnotežena, čeprav je družbenih geografov nekaj več (devet) kot fizičnih (sedem), kajti družbena geografija je bolj razvejana kot fizična.

Podobno sliko nam pokaže primerjava med družbeno in fizično geografijo, če pogledamo število magisterijev in doktoratov. $\mathrm{V}$ tem dvajsetletnem obdobju je bilo 14 magisterijev iz fizične in 45 iz družbene geografije, doktoratov je bilo 16 iz fizične in 31 iz družbene geografije. To so bili magisteriji in doktorati iz posameznih fizično- in družbenogeografskih vej. Iz kompleksne fizične geografije pa so bili trije magisteriji. Gotovo bi bilo koristno za samo fizično in celotno geografijo, da bi se povečalo število preučevanj na ravni magisterija in 
doktorata. Tako bi bilo še več novih dognanj in bi bolje poznali fizičnogeografske značilnosti naše države.

Če se na kratko ustavimo pri posameznih vejah, se nam bo dopolnila slika, kaj vse je bilo narejeno v zadnjih dvajsetih letih.

$\mathrm{V}$ dveh desetletjih se je pri preučevanju in pedagoškem delu v okviru geomorfologije razvrstilo več raziskovalcev in učiteljev. Svoje delo je uspešno nadaljeval Ivan Gams, ki se je posvečal zlasti preučevanju kraškega reliefa. Nadaljeval je tudi predmet geografija krasa, ki pa je bil zasnovan širše, ne samo geomorfološko; bolj naj bi bil regionalnogeografski. I. Gams je svoje delo nadaljeval do upokojitve leta 1989. Predmet geomorfologija je za njim prevzel Jurij Kunaver, ki pa se je posvečal preučevanju pleistocenske poledenitve pri nas; delno tudi periglacialnim pojavom. Svoje delo je usmerjal tudi v preučevanje glaciokrasa. Zelo podrobno je preučeval visokogorski kras, kjer je v naši geografiji oral ledino, poglabljal se je tudi v geomorfologijo ledeniškega reliefa.

Jurij Kunaver je več let predaval tudi geografijo krasa. Po upokojitvi leta 1999 je prevzel geomorfologijo Karel Natek, ki je sprva nadaljeval tudi s predavanji iz geografije krasa, a jih je nekaj let kasneje prepustil Andreju Mihevcu (Inštitut za raziskovanje krasa ZRC SAZU iz Postojne) in Urošu Stepišniku. Njegovo raziskovalno delo je še naprej usmerjeno v reševanje geomorfoloških vprašanj in preučevanje naravnih nesreč.

Za boljše in temeljitejše poznavanje zemeljskega površja in sploh pokrajine so še vedno potekala predavanja iz geologije, ki jo je nekaj let predaval Stanko Buser, za njim jih je prevzel Vasja Mikuž in od študijskega leta 2008/09 naprej Andrej Šmuc (Oddelek za geologijo Naravoslovnotehniške fakultete). Vaje iz geologije za geografe je nekaj let vodila Sabina Popit, ki je sodelovala tudi pri geografiji krasa. Na Oddelku za geografijo se je zaposlila leta 1996. Nekaj časa je vodila tudi vaje iz geomorfolgije; poleg tega pa je bilo njeno delo precej usmerjeno v didaktiko geografije.

V okviru fizične geografije je deloval tudi Marjan Bat, ki je leta 1989 magistriral z delom Fizična geografija gorskega sveta. Vodil je vaje iz geomorfologije, metodologije fizične geografije in geografije krasa. Preučeval je vplive fizičnogeografskih dejavnikov na podobo kulturne pokrajine v gorskem svetu, Škofjeloško hribovje in fizičnogeografske značilnosti Ljubljanskega polja, odnose med rabo tal in naklonom površja ter vplive fizičnogeografskih dejavnikov na rabo tal. Leta 1991 je odšel na Hidrometeorološki zavod Republike Slovenije.

Vaje iz geomorfologije je v letih 1991-94 vodil Mauro Hrvatin, ki se je tudi raziskovalno usmerjal v preučevanje reliefa, nato je odšel na Geografski inštitut Antona Melika ZRC SAZU. V letu 1998 je začela te vaje in vaje iz geografije krasa voditi Irena Mrak. Tudi njeno raziskovalno delo je bilo usmerjeno v preučevanje reliefa. V magistrskem delu je predstavila rezultate raziskovanja sledov pleistocenske morfogeneze v porečju Tržiške Bistrice. Preden se je zaposlila na Raziskovalnem centru Oddelka za geografijo (2006), so pri njej študentje opravljali tudi vaje iz klimatogeografije.

Leta 2003 je prevzel vaje iz geomorfologije in geografije krasa Uroš Stepišnik. Njegovo raziskovalno delo je usmerjeno v problematiko kraškega reliefa. Tako je v diplomskem delu preučeval udornice na Postojnskem krasu, v doktorskem delu pa udornice na slovenskem krasu. 
V geomorfologiji se je torej nadaljevalo preučevanje kraškega površja, sledov pleistocenske poledenitve, periglacialnih pojavov, glaciokrasa in še več drugih. Geomorfologi iz Oddelka za geografijo so predstavili rezultate svojih preučevanj na mnogih domačih in tujih strokovnih posvetovanjih ter zborovanjih, npr. Mednarodne geografske unije, pa v delovni skupini za posege na krasu pri Mednarodni geografski uniji in na zborovanjih v nekdanjih jugoslovanskih republikah. Pomembno je bilo tudi to, da so bili ti geomorfologi zelo dejavni pri osnovanju in tudi pri nadaljnjem delovanju Geomorfološkega društva Slovenije (J. Kunaver, I. Gams, K. Natek). K. Natek je bil v letih 1990-1994 prvi predsednik tega društva. To društvo združuje poleg njih tudi vrsto geomorfologov in geologov iz drugih inštitucij, kar vse prispeva h kakovosti raziskovanja površja pri nas. J. Kunaver je bil tudi pobudnik strokovnih srečanj jugoslovanskih geomorfologov in je organiziral prvo tovrstno srečanje $v$ Bovcu leta 1986.

Podobno kot $\mathrm{v}$ geomorfologiji se je pedagoško in raziskovalno delo nadaljevalo tudi $\mathrm{v}$ klimatogeografiji. Ta se je še naprej opirala na meteorologijo za geografe, ki so jo predavali Zdravko Petkovšek, Tomaž Vrhovec in Jože Rakovec. Predavanja iz klimatogeografije je imel Ivan Gams do upokojitve leta 1989, nato je še eno študijsko leto predaval ta predmet honorarno. Za njim je prevzel predavanja iz klimatogeografije Jurij Kunaver. V letu 1990 je začel z vajami iz klimatogeografije takrat mladi raziskovalec Darko Ogrin, ki naj bi se usmeril tudi v preučevanje klimatogeografskih vprašanj. Med njimi so bila vprašanja iz dendroklimatologije in tudi dendrokronologije. D. Ogrin je svoje raziskovalno, kasneje pa tudi pedagoško delo iz te veje fizične geografije nadaljeval, ko je bil izvoljen v docenta in ga opravlja še tudi sedaj. Največ pozornosti posveča topoklimatskim in lokalnoklimatskim vprašanjem, precej pa tudi historični klimatologiji. D. Ogrin se je posvečal preučevanju še drugih klimatogeografskih vprašanj: $v$ magistrskem delu se je ukvarjal s preučevanjem klimatske pogojenosti drevesnega prirastka $\mathrm{v}$ Sloveniji, pri doktoratu pa je bila njegova tema: Mezoklimatogeografija Koprskega primorja in njene spremembe v zadnjih stoletjih. V zadnjih letih se vsaj delno posveča klimatogeografski problematiki tudi Matej Ogrin.

V nadaljnjem preučevanju podnebnih razmer pri nas, pa tudi v sosedstvu, bo vedno bolj prihajala v ospredje prizadetost ozračja zaradi vplivov delovanja človeka. $\mathrm{V}$ to naj bi bila usmerjena tudi preučevanja na Oddelku za geografijo, saj bodo njihovi rezultati pomembni tudi pri pedagoškem delu. Mladi geografi - pa naj bodo šolniki ali zaposleni v nepedagoških poklicih - morajo dobro spoznati, kakšni so vplivi človeka na podnebje v slovenski pokrajini in tudi izven nje.

Tako kot v letih pred 1989 je na Oddelku za geografijo nadaljeval predavanja iz hidrogeografije Darko Radinja. Ob intenzivnem pedagoškem delu se je loteval aktualnih vprašanj vodnih razmer pri nas. Zlasti je precej časa posvečal preučevanju oskrbe s pitno vodo po posameznih naseljih v Sloveniji. Zelo temeljito se je vključil v preučevanje poplav in poplavnih območij pri nas, ki se je začelo že pred letom 1988. Pomembna je bila priprava metodologije preučevanja poplavnih območij (Radinja in sod. 1974) in prva konkretna preučitev poplavnega območja Pšate (Radinja in sod. 1976). S pomočjo te metodologije so bila kasneje raziskana mnoga poplavna območja po Sloveniji. Veliko dela je vložil v preučevanje hidrogeografije Rateške pokrajine in talne vode v Gornjesavski dolini ter v raziskovanje Blejskega in Bohinjskega jezera. 
Darko Radinja je predaval hidrogeografijo do upokojitve leta 1996. Za njim je prevzel predavanja iz tega predmeta Dušan Plut, ki ga predava še sedaj. V svojem raziskovalnem delu se je mdr. posvečal vprašanjem geografske problematike vodnih virov in delno spoznavanju prizadetosti voda v okviru varstva okolja. Za hidrogeografijo kot eno od vej fizične geografije in za študente je pomemben izid njegovega učbenika iz hidrogeografije z naslovom Geografija vodnih virov (2000), ki je prvi te vrste pri nas.

$\mathrm{V}$ hidrogeografsko problematiko na pedagoški in raziskovalni plati se je začela leta 1996 usmerjati Valentina Brečko Grubar, ki je kot asistentka vodila vaje iz tega predmeta. V magistrskem delu se je posvetila vplivu pokrajinskoekoloških dejavnikov na vodno oskrbo Ljubljane. Disertacija pa je prinesla nova spoznanja o trajnostnem sonaravnem gospodarjenju z vodnimi viri v porečju Kamniške Bistrice. Svoje delo je nadaljevala do leta 2007, ko je odšla na Fakulteto za humanistične študije v Kopru, za njo pa je vaje iz hidrogeografije prevzel Tajan Trobec. Svoje raziskovalno delo usmerja v preučevanje hidrogeografskih vprašanj.

Prav problematika voda v slovenski pokrajini postaja vedno bolj pereča, saj so tekoče vode kot tudi talna voda že dokaj onesnažene, tako da bodo raziskovanja vode v naši pokrajini - pa naj bo to v okviru hidrogeografije ali varstva okolja - postajala vedno bolj pomembna. S tem imajo hidrogeografi na Oddelku za geografijo široko polje svojega preučevanja.

Kot pri ostalih vejah fizične geografije, se je pedagoško in raziskovalno delo nadaljevalo tudi pri pedogeografiji in fitogeografiji. Predavanja in vaje iz obeh vej je vodil Franc Lovrenčak, raziskovalno pa se je ob koncu osemdesetih in v začetku devetdesetih let posvečal preučevanju zgornje gozdne meje v našem gorskem svetu. V preučevanju prsti je bil večji poudarek na iskanju zvez med odejo prsti in reliefom, npr. v Planici, na kraškem reliefu in drugod. Zaradi vsebinske jasnosti in neločljive povezanosti prsti in živih (rastlinstva in živalstva) sestavin pokrajine je bil leta 1991 predmet preimenovan $\mathrm{v}$ pedogeografijo z biogeografijo. $\mathrm{V}$ biogeografiji, kjer se obravnavata rastlinstvo in živalstvo kot pokrajinotvorni sestavini, je bilo živalstvu posvečeno manj pozornosti. Zoogeografija ostaja še naprej na pedagoški ravni, na raziskovalni jo bo potrebno $\mathrm{v}$ geografiji šele razviti.

Za potrebe študentov, pa tudi tistih, ki so jim blizu prsti in žive sestavine pokrajine, sta bila izdana dva njegova učbenika: Pedogeografija (1994) in Osnove biogeografije (2003). V sodelovanju s predavateljico pedogeografije in biogeografije na Filozofski fakulteti v Mariboru Ano Vovk Korže sta bila izdana dva priročnika o laboratorijskih analizah prsti in terenskemu preučevanju prsti z geografskega vidika.

Leta 1999 je prevzel vaje iz pedogeografije in biogeografije asistent stažist Blaž Repe. Vaje iz pedogeografije je vodil do zimskega semestra 2007/2008. V letnem semestru istega šolskega leta je vaje iz biogeografije prevzela Mojca Ilc, v naslednjem študijskem letu pa je vaje iz pedogeografije in biogeografije prevzel Tajan Trobec. Repetovo raziskovalno delo je usmerjeno v preučevanje prsti v pokrajini. Tako se je v magistrskemu delu posvetil prikazu degradacije prsti v Sloveniji, v disertaciji pa se je lotil pereče problematike pedogeografske karte in jo utemeljil ter prikazal tudi njeno uporabnost v geografiji. Po odhodu F. Lovrenčaka v pokoj je leta 2007 prevzel predavanja iz pedogeografije z biogeografijo.

Pri preučevanju prsti in rastlinstva ter živalstva v slovenski pokrajini postaja pomembno, da so vse tri sestavine pokrajine vedno bolj pod vplivi človekovih posegov, večkrat tudi ne- 
gativnih, $\mathrm{s}$ tem pa so predmet preučevanja tudi z geografskega vidika, pa naj bo to v okviru varstva okolja ali pedogeografskih raziskovanj, npr. erozije prsti.

Odprtost za spoznanja, do katerih so prišli drugi fizični geografi, se kaže tudi v tem, da so prihajali na Oddelek za geografijo tuji gosti, ki so predavali o raznih fizičnogeografskih temah, npr. S. Belij je predstavil preučevanja periglacialnih pojavov v Prokletijah (Črna gora), J. Riđanović je predaval o hidrogeogarfskih problemih, F. Zatkalik o zgornji gozdni meji, I. Ružek o invazivni vegetaciji in posledicah njenega prodora v pokrajini in na ljudeh.

Večji del fizičnogeografskega preučevanja je potekal po posameznih fizičnogeografskih vejah. Skupnega predmeta fizična geografija na Oddelku za geografijo že dolgo časa ni bilo več. V šestdesetih letih je predaval splošno geografijo I - fizično geografijo (v 1. letniku) Darko Radinja, splošno geografijo II - družbeno geografijo (v istem letniku) pa Igor Vrišer. Šele s spremembo učnega načrta se je leta 1989 v njem ustalil predmet Metodologija fizične geografije, ki so jo nato vrsto let predavali različni predavatelji ( D. Radinja, J. Kunaver, F. Lovrenčak, D. Ogrin). Pri tem predmetu je šlo za prikaz metodologije preučevanja v posameznih vejah fizične geografije. Z novimi spremembami učnega načrta v letu 1997 tega predmeta ni bilo več.

Pomembno prelomnico pomeni študijsko leto 2008/09, ko se je zopet začelo s predavanji iz fizične geografije. To je bilo z uvedbo prve stopnje univerzitetnega študija geografije po bolonjskem sistemu, ko so stekla predavanja iz fizične geografije I (geomorfologija in klimatogeografija) ter fizične geografija II (hidrogeografija in pedogeografija z biogeografijo). Zaradi velike razvejenosti in obširnosti posameznih fizičnogeografskih vej je možno predavati te vsebine samo na ta način. Podobno je tudi na drugih univerzah, npr. v Bratislavi.

D. Radinja (1989) je zapisal, da bi bilo potrebno v okviru fizične geografije - kljub specializaciji - osnovati splošno fizično geografijo. Morda pa bo prav uvedba obeh fizičnih geografij privedla do splošne fizične geografije, ki jo bo predaval en predavatelj.

Delno je prišlo do sintetične fizičnogeografske obravnave leta 1997, ko je začel Darko Ogrin predavati Fizično geografijo Slovenije. S tem so študenti dobili vsaj za domačo državo $\mathrm{v}$ enem predmetu pregled njenih naravnogeografskih razmer. Vaje iz tega predmeta je leto kasneje prevzela asistentka Irena Mrak, za njo pa asistent Blaž Repe. Posebej je potrebno poudariti, da je na osnovi predavanj in poznavanja naravnih razmer Slovenije izšel učbenik Aplikativna fizična geografije Slovenije (Ogrin in Plut 2009). Z njim smo dobili sodoben in dokaj celosten prikaz fizične geografije Slovenije, dopolnjen z novimi rezultati tovrstnih preučevanj.

Za razvoj in pomen fizične geografije je bilo pomembno tudi to, da so fizični geografi z Oddelka za geografijo predavali tudi drugod. Kmalu so se dejavno vključevali v delo na novo nastalem Oddelku za geografijo Pedagoške akademije (sedaj del Filozofske fakultete) Univerze v Mariboru. Zaradi pomanjkanja predavateljev so predavali vrsto let tamkajšnjim študentom in skrbeli za mlade asistente, ki so se postopoma vključevali v pedagoško in raziskovalno delo, ter po magisterijih in doktoratih prevzeli delo univerzitetnih učiteljev. Tako so predavali geomorfologijo (J. Kunaver), pedogeografijo in biogeografijo (F. Lovrenčak) in ekološko geografijo (D. Plut).

Od 1990 do 1992 je Jurij Kunaver na Oddelku za krajinsko arhitekturo na Biotehniški fakulteti predaval fizično geografijo, po 1993 je za njim ta predavanja nadaljeval Karel 
Natek. D. Ogrin je od leta 2002-2007 predaval osnove fizične geografije in fizično geografijo Sredozemlja študentom Oddelka za geografijo Fakultete za humanistične študije Univerze na Primorskem v Kopru.

Fizični geografi z Oddelka za geografijo so bili dejavni tudi pri pisanju naravnogeografskih poglavij v monografskih delih: Geografiji Slovenije (I. Gams, F. Lovrenčak,), Naravi Slovenije (J. Kunaver, D. Ogrin), Geografskem atlasu Slovenije, pri pisanju številnih gesel v Enciklopediji Slovenije in pri Geografskem terminološkem slovarju.

$\mathrm{V}$ tem obdobju so bili fizični geografi iz Oddelka za geografijo povezani s tokovi fizične geografije v drugih državah. Tudi tam je delo večinoma potekalo po posameznih vejah in le malo po kompleksnem fizičnogeografskem preučevanju. Morda je zanimiv primer slovaških fizičnih geografov, ki so se združili v projektu pri preučevanju določenega skupnega problema.

Ljubljanski fizični geografi, ne le geomorfologi, so rezultate svojega raziskovalnega dela predstavili na mnogih strokovnih posvetih, mednarodnih zborovanjih in simpozijih. Njihove razprave so izšle v številnih tujih strokovnih glasilih in drugih publikacijah, npr. GeoJournal, Geografia fisica e dinamica quaternaria, Acta geographica Croatica, Studia geomorphologica Carpatho-Balcanica, Acta universitatis palackianae olomoucensis, Facultas rerum naturalium, Geographica, Moravian geographical reports, Cave and karst Science, Zeitschrift für Geomorphologie, International journal of speleology, Mitteilungen der Österreichischen Geographischen Gesellschaft, Klagenfurter Geographische Schriften, Catena itn.

$\mathrm{Na}$ ta način so posredovali svoja spoznanja drugim fizičnim geografom, obogatili geografijo in s tem prispevali k razvoju te znanosti. Povezanost $\mathrm{z}$ geografijo v tujini je gotovo nujno potrebna tudi nadalje, saj se bo samo na ta nič lahko fizična geografija bogatila in pokazala dosežke svojih preučevanj doma in drugim geografskim šolam. Ne sme pa ostati prezrto, da so tudi tuji fizični geografi s svojimi prispevki v našem strokovnem slovstvu bogatili našo geografijo, npr. M. Vysoudil (klimatogeografija), Z. Bičanić (oceanografija), P. Plesnik (vegetacijska geografija), K. Urushibara (pedogeografija) idr.

$\mathrm{V}$ zadnjih dvajsetih letih se je nadaljevalo tudi delo v fizičnogeografskem laboratoriju na Oddelku za geografijo. Analitično delo je potekalo v dvojni smeri: pedagoški in raziskovalni. Študenti so se na praktičen način seznanjali s številnimi laboratorijskimi analizami. Raziskovalci z Oddelka za geografijo pa tudi od drugod so s pomočjo analiz dobili podatke, ki so jih potrebovali pri svojem delu. V njem je bilo opravljeno zelo veliko analiz prsti in vode, pa tudi kamnin. Podatki teh analiz so nudili kvantitativno osnovo mnogim razpravam, ki so izšle v strokovni literaturi ali referatom na raznih zborovanjih. Gotovo bi bilo koristno, da bi se z novimi metodami in načini (tudi računalniško) še naprej vršilo analitsko delo, saj bo tako mogoče še bolj temeljito podpreti in utemeljiti preučevanja različnih naravnih dejavnikov slovenske pokrajine.

$\mathrm{H}$ kompleksnemu poznavanju pokrajine $\mathrm{z}$ vidika povezave vseh naravnih pokrajinotvornih sestavin so veliko prispevale tudi terenske vaje iz fizične geografije za študente. Te vaje so potekale in še potekajo v različnih predelih Slovenije, npr. v Planici, Kančevcih, Beli krajini, na Debelem rtiču itn. S tem so fizični geografi nudili študentom celovitejše poznavanje določenih pokrajinskih enot Slovenije in boljše razumevanje tudi njenih družbenogeo- 
grafskih značilnosti. Pomembno je to, da je prav iz teh preučevanj nastalo kar nekaj študij in celo knjiga Bela krajina in Krajinski park Lahinja (2008). Prav poglavja o krajinskem parku Lahinja so rezultat večletnega fizičnogeografskega preučevanja v okviru teh terenskih vaj.

\section{ZAKLJUČEK}

D. Radinja (1989) vidi v bodočem razvoju fizične geografije študij fizičnogeografske regionalizacije. Nekaj poskusov v tej smeri je pri nas že bilo, vendar je ena od nalog naše sedanje fizične geografije prav ta regionalizacija cele Slovenije in njenih posameznih delov. V nadaljnjem razvoju fizične geografije, ne samo na Oddelku za geografijo, je pomembno kvantitativno vrednotenje raznih pokrajinskih pojavov. S tem bo fizična geografija ohranila svoje mesto v geografiji in tudi v prostorskih znanostih. Pomembno je tudi, da fizični geografi usmerjajo svoje raziskovalno delo v sodobne probleme v naši pokrajini, tako pri preučevanju naravnih nesreč in prizadetosti geografskega okolja (vode, zraka, prsti in rastlinstva). Tudi sodelovanje pri regionalnogeografskih monografijah posameznih delov Slovenije ali cele Slovenije bo za fizične geografe nujno, saj bodo le-te brez njihovega dela nepopolne. Nenazadnje pa bi se morali fizični geografi poglabljati tudi v teoretična vprašanja, razvijati fizičnogeografsko misel in s tem prispevati k teoriji geografije, pri nas pa tudi izven naše domovine.

\section{Viri in literatura}

Bela krajina in Krajinski park Lahinja. Znanstvena založba Filozofske fakultete, Oddelek za geografijo. Ljubljana 2008.

Fizična geografija pred novimi izzivi. Dela 20. Ljubljana 2003.

Geografija in aktualna vprašanja prostorskega razvoja. 70 let geografije na ljubljanski univerzi. Dela 6. Ljubljana 1989.

Ilešič S. 1950: Slovenska geografija v 30 letih ljubljanske univerze. Geografski vestnik 22, str. 215-218. Ljubljana.

Ilešič S. 1969: Geografija. V: Petdeset let slovenske univerze v Ljubljani. Ljubljana.

Lovrenčak, F. 1994: Pedogeografija (univerzitetni učbenik). Oddelek za geografijo Filozofske fakultete. Ljubljana.

Lovrenčak, F. 2003: Osnove biogeografije (univerzitetni učbenik). Oddelek za geografijo Filozofske fakultete. Ljubljana.

Ogrin, D., Plut, D. 2009: Aplikativna fizična geografija Slovenije (univerzitetni učbenik). Znanstvena založba Filozofske fakultete. Ljubljana.

Plut, D., 1989: Ob 70-letnici poučevanja in raziskovanja geografije na ljubljanski univerzi. Dela 6, str. 1-8. Ljubljana.

Plut, D. 2000: Geografija vodnih virov (univerzitetni učbenik). Oddelek za geografijo Filozofske fakultete. Ljubljana.

Poročila o delu Filozofske fakultete v Ljubljani od 1988/89 do 2002/03. Ljubljana.

Radinja, D., Šifrer, M., Lovrenčak, F., Kolbezen, M., Natek, M. 1974: Geografsko proučevanje poplavnih področij v Sloveniji (delovni program Inštituta za geografijo SAZU in smernice za proučevanje). Geografski vestnik 46, str. 131-146. Ljubljana. 
Radinja, D., Šifrer, M., Lovrenčak, F., Kolbezen, M., Natek, M. 1976: Geografske značilnosti poplavnega področja ob Pšati. Geografski zbornik 15, str. 7-160. Ljubljana.

Radinja, D. 1989: Sedemdeset let fizične geografije na ljubljanski univerzi. Dela 6, str. 9-21. Ljubljana.

Razvojne možnosti Slovenije - Bodočnost mest. 80. letnica Oddelka za geografijo. Dela 14. Ljubljana 1999.

Stanovnik, B. (ur.) 1999: Biografije in bibliografije univerzitetnih učiteljev in znanstvenih delavcev in sodelavcev. Univerza v Ljubljani, 5. knjiga, III. del, 1987-1996. Ljubljana.

Vovk Korže A. 1999: Pomen Oddelka za geografijo Filozofske fakultete v Ljubljani z vidika razvoja slovenske geografije s posebnim poudarkom na razvoju geografije v Mariboru. Dela 14, str. 23-25. Ljubljana.

\section{THE DEVELOPMENT OF PHYSICAL GEOGRAPHY AT THE UNIVERSITY OF LJUBLJANA}

\section{Summary}

During the last two decades (1989-2009), the development of physical geography and of its particular branches was based on firm grounds, established in previous decades. The study of abiotic and biotic components of landscape, the physical geographers contributed a good deal to the geographical knowledge of Slovenia as a whole and of its particular regions. The results of scientific research were presented to the public during many professional meetings and through the publishing of scientific and professional papers at home and abroad as well and they can be evaluated as an important contribution to the general geographical knowledge. However, in the background of last two decade's work, we can feel the positive ambitions for some kind of synthesis, where the knowledge of particular branches would be united into a new physical geography.

(Translated by Karel Natek) 